\title{
"DESPITE THESE MANY CHALLENGES": THE TEXTUAL CONSTRUCTION OF AUTONOMY OF A CORPORATISED SOUTH AFRICAN UNIVERSITY
}

\author{
Brenden Leam Gray \\ University of Johannesburg, South Africa \\ brendenyeo@gmail.com
}

\section{ABSTRACT}

The paper critically discusses how the notion of autonomy is textually constructed in the neo-liberal discourses of a corporatised public South African higher education system. By employing the methods of critical discourse analysis (CDA), I analyse two selected texts written by various leaders connected to the University of Johannesburg between 2013 and 2014. This includes a newspaper article written by the vice chancellor and a strategic document produced by the University of Johannesburg in 2014. The strategic document, the focus of this article, is a governance text that operationalises neo-liberal ideas and encourages academics, through its understanding of autonomy, to conform to the values of global competition, entrepreneurship and performance as ends in themselves. The operationalisation of these values leads to a denial of the social which I argue renders the the problems of unemployment, poverty and inequality as rhetorical tropes in these texts. The paper implicitly argues that the concept of autonomy is highly problematic.

Keywords: autonomy; autonomy and legitimacy; corporatisation; critical discourse analysis; governmentality; language; legitimation; neo-liberalism; South African public higher education; University of Johannesburg's Global Excellence and Stature Strategy

\section{INTRODUCTION: THE CORPORATISATION OF SOUTH AFRICAN HIGHER EDUCATION}

The neo-liberalisation of public higher education policy and corporatisation of South African public universities is well underway (Baatjes 2005; Bertelsen 1998; Chetty and Merret 2014; Habib 2009, 2013; Mamdani 2007; Ntshoe 2004; Southall and Cobbing

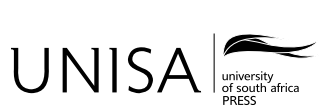

Education as Change www.educationaschange.co.za Volume 21 | Number 3 | 2017 | \#2481 |21 pages https://doi.org/10.17159/1947-9417/2017/2481 ISSN 1947-9417 (Online), ISSN 1682-3206 (Print)

(C) The Author(s) 2017 
2006; Tikly 2003; Spreen and Vally 2006; Vally 2007b). The shift to corporatisation is said to facilitate higher levels of "institutional autonomy," a quality that may be said to enhance critical aspects of the university such as "academic freedom" (Bentley, Habib, and Morrow 2006; Du Toit 2000, 2007). However, what this sort of autonomy means in a context of severe inequality and in a situation where the purpose of higher education is being challenged through student protest remains unclear.

The paper was conceptualised at a time when the South African \#FeesMustFall student protests reached their height in early 2016. In October and November of 2015 campuses across South Africa exploded. Students across the country expressed their dissatisfaction with the institutions and the system of higher education. A major complaint was that learning had become commodified and as a result was excluding the majority of poor and working-class youth from participating in higher education. Added to this was the complaint that higher education had become not only financially exclusionary but that university curricula remained colonial and elitist-epistemically exclusive. The result of the protests was that 16 of the major campuses were shut down in late 2015 and many in early 2016.

The study identifies policy and governance texts that express at various levels how the corporatised university understands itself, especially its purpose and autonomy in society by employing CDA (critical discourse analysis). The focus of the first section of the paper is on documents in the period leading up to the seminal \#FeesMustFall protests of 2015. The paper deals with various texts produced by leaders of the University of Johannesburg in the years before the protests, texts that in their discussion of autonomy foreground strongly understandings of purpose. I have selected these texts because they contain the contradictions in the construction of autonomy in what is a fraught post1994 situation in the higher education landscape in South Africa - one where fees-based education, the gradual privatisation of public education, the outsourcing of university staff, institutional racism, and colonial curricula are the norm.

The University of Johannesburg (UJ) is an ideal case for the study of neo-liberal governmentality; as an institution that grew out of a post-apartheid merger, it is markedly and visibly corporatised, neo-liberalised and neo-liberalising. As teaching educators at UJ we experience the institution as one where performativity and governmentality is "at work" in its culture and in terms of the way that the university represents, understands and speaks to and about itself. The language that the university uses to position itself as a relatively new institution in the global market of higher education is openly corporate and entrepreneurial. Its ambitions to "be" neo-liberal, and act in private, for-profit terms are expressed not only in rhetorical terms but also in strategic and organisational terms: managerial and academic hierarchies are organised around the lines of profitability and efficiency.

The first text that I examine is an online article written by the UJ vice chancellor, Ihron Rensburg, in 2013 for Business Day entitled "Regulatory Overkill Threatens Academic Autonomy in South Africa." It argues implicitly for the corporatisation of the university and against state interference in higher education. The second set of texts 
that are analysed are extracts from governance documents including the "Strategic Plan 2025: Tracking Progress towards Achieving Global Excellence and Stature" (hereafter referred to as GES). I analyse the foreword written in 2014 by the UJ council chairperson, Professor Roy Marcus, and the introduction by the vice chancellor, Professor Ihron Rensburg. The document, as one that embodies the strategic vision of the corporatised university, largely operationalises the neo-liberal ideas contained in the Business Day article, and, as I argue in the conclusion, this sets up some troubling implications. As a set, the texts that I analyse represent the discourses of corporatisation at different levels - at the level of the journalistic, policy and in the strategic language of the university itself.

\section{CRITICALLY ANALYSING GOVERNMENTALITY IN HIGHER EDUCATION}

Governmentality is a term developed by Foucault to describe the manner in which the ruling classes exert their power in liberal societies. The rise of neo-liberal governmentality, as an innovation of liberal government, has coincided with the reform of the public higher education sector globally as a result of a widespread reduction of social spending and the growing expectation that public institutions should become financially "sustainable" enterprises. Consequently, public institutions have largely been forced to be more self-sufficient and to adopt business models in order to survive. The implementation of public sector management in higher education (Ball 2012a) has supported this process. Aimed at enhancing accountability and transparency in the public system, public sector management has exposed higher education to corporate surveillance techniques and unfamiliar governance strategies that have imposed greater managerial control over the academic project. The dominance of knowledge economy discourses in higher education has cast research and education in instrumental terms as profitable enterprises (Slaughter 2014).

Taking the form of "market universities" (Pendlebury and van der Walt 2006, 83) public institutions are hybrid and may have a complicated and confused understanding of their own powers, responsibilities, limits and thus of their autonomy. With the rollback of the state as a guarantor of social rights (Wacquant 2009) and its new function as an enabler for capitalist development this lack of a coherent purpose appears inevitable. Vulnerable to market forces, reformed from without and from within, experiencing both encouragement and resistance to corporatisation from academics, public universities might be thought to be experiencing a crisis of identity (Barnett 2011).

The double movement to commodify education and to control the educational project, post the negotiated settlement, has raised a new set of concerns about the autonomy of universities (du Toit 2000; Tikly 2003). New "internal" dynamics linked to the "managerial revolution" might be seen as threats to academic freedom (Southall and Cobbing 2006) whilst existing dynamics such as state regulation and problematic restructuring regimes (Cooper 2015) are externally threatening academic autonomy. 
Corporate norms inform how academics and their purpose are rhetorically constructed. The report Academic Freedom, Institutional Autonomy and the Corporatised Public University in Contemporary South Africa (Bentley, Habib, and Morrow 2006), an important report commissioned by the Council for Higher Education (CHE), is a good example of the extent to which corporate governmentality has been accepted and even celebrated in South African higher education.

The argument contained in texts such as these tends to proclaim that a liberal conception of academic purpose best suits knowledge production, social justice and learning. As the authors of this text argue, if the conditions of the "dispersal of powers" and "income diversification" (Bentley, Habib, and Morrow 2006, 24, 27) are met, the higher education sector can become an equal stakeholder, among others-including the state - in realising a better society. Universities must make an agential claim and relate sufficiently to "marginalised sections of society." This requires that universities become corporate bodies with their own "moral rights" (Bentley, Habib, and Morrow 2006, 16) existing within the broader marketplace of ideas.

Institutional autonomy is asserted as a "positive right" - one that guarantees the nurturance of "academic entrepreneurialism" in fragile "discourse communities" (Bentley, Habib, and Morrow 2006, 16, 20). Further to the point, armed with a "corporate conception" of its own rights, the university will not only realise its own freedoms but will ably engage with the "interests of a variety of stakeholders," including marginalised people (Bentley, Habib, and Morrow 2006, 29):

[A]cademic entrepreneurialism needs to be encouraged, valued, and actively built in the public higher education system. This is because such active marketing of the academy is necessary to relate academic work to the interests of a variety of stakeholders, including marginalised sections of society. This is often not understood either by those who advocate academic entrepreneurialism or their critics. Entrepreneurialism does not simply imply the generation of money. In its wider interpretation, it involves the engagement of the academy with the immediate concerns of the society within which it is located.

Constructed in this way, institutional autonomy becomes what protects the main purpose of the university - its capacity to "relate" is presented as a social justice issue and this is predicated on the liberalisation of academic work.

Here "active marketing" is the "necessary" principle or "mechanism" by which the university "relates" to marginalised peoples and for them paradoxically it is heteronomy that is the principle that defines the university's autonomy. The state is here characterised as working against justice itself, frustrating the university's attempt to be a good brand, to speak to society in the free and open "contestation of empowered stakeholders" (Bentley, Habib, and Morrow 2006, 24). It is no wonder then that the authors of this text concluded that academics should not wait till some distant "institutional revolution [for] better resourced or even free higher education system," ceases with "continuous complaints about the neo-liberal character of our world" and understands that "academic freedom needs to be constructed through the contestation 
of empowered stakeholders, which itself is a product of the messy process of higher education reform and entrepreneurial academic practice" (Bentley, Habib, and Morrow 2006, 30). This might be a typical expression of liberal governmentality (Lasslett 2015), or "vitalpolitik" where policies and (market) mechanisms (Fairclough 2008, 49) must be invented to construct a set of moral norms.

Since the 1990s market-measurable and performance-based funding formulas have resulted in what might be considered to be lower levels of academic freedom. Austerity (Pendlebury and van der Walt 2006) has meant that universities are less likely to engage in community and developmental projects, focusing their work on what counts and can be counted. The introduction of performance-based systems has made academic work seem more precarious and such systems may, beyond being controlling, encourage the colonisation of intellectual life in academia (Nash 2006). Although access to higher education in post-apartheid South Africa may have widened, due to uneven processes of massification this hasn't been matched by state funding.

As is suggested by Bentley, Habib, and Morrow (2006) corporatisation is not necessarily a bad thing. Bringing business into academic life might be said to enhance research output, efficiency, quality in teaching and unleash entrepreneurial freedoms in academia. Ironically, what has become the most stable feature of academic life in South African public universities is corporate governance (Jansen 2006, 19; Nash 2006, 6-10) itself. This has direct bearing on how the higher education sector conceives of autonomy, which is in turn reflected in the texts that its leaders produce for the outside world and for itself.

Neo-liberalism is an innovation that allows the state to exert its power over an entire population through the dispersal of governmental rationalities (Peters 2009, 98). The suppression of academic dissent and critical inquiry does not take place directly through penalties, sanctions, policing, or surveillance, but through the discursive activation of particular institutional agents.

Foucault's notion of "governmentality" is useful because it shows how autonomy is a central concern to liberal and neo-liberal regimes. The concept unmasks the "autonomous" individual's capacity for self-control and agency (Lemke 2002, 4). The reordering sets up communities as targeted populations, citizens as individual consumers, and academics as knowledge workers. Its aim appears to be to responsibilise individuals as productive in a special way, as "entrepreneurs of oneself" (du Gay 2006, 301; Tikly 2003, 164). Individuals are subjectified as human resources, available for the extraction of value, but at the same time appear to themselves as self-governing subjects. Compliance with the state and capital is achieved not simply through the application of external coercive power, but through complex processes manufacturing consensus. The subject must remain an active, desiring and willing agent. Under the logic of enterprise, individuals must be incentivised by their own interests, taking commercial imperatives as given and universal. Subjectivity is not something left to the individual but a "key site of political struggle" (Ball 2015, 3). 
"The exercise of power is rationalised [not] as forms of domination but technologies of government that may lead to a state of domination" (Dean cited by Ball 2013, 121). Under neo-liberalism, the illusion that choice is distributed throughout the system creates a powerful form of misrecognition in the exercise of symbolic power. Power is realised as a discursive system. Those who discursively control the field of judgment and produce legitimising texts are well positioned by corporate governance to set the terms of academic performance through strategic planning documents, the adoption of measuring techniques for monitoring, and directing academic behaviour.

Governmentality therefore has a strong performative relational element, "enrolling" (Rose and Miller 2008) and "producing rather than constraining subjects" (Ball 2013, 19).

Theoretically, autonomy is a complex relational phenomenon that marks a field limit, signified variously by the social conditions that produce consciousness; as a concentration of a species of capital in social space and ideologically, masking of the social genesis of a field (Bourdieu 1991, 5). Autonomous fields in contrast to heteronomous ones disguise their structure, entry criteria and the positions that constitute them, thus appearing disinterested. Janus-faced, autonomy can be the principle of domination (Bourdieu 2005, 168), but might also be retained by academics to protect the possibility for rational thinking (Bourdieu 1991, 661). Too often autonomy is doxic in its formulation, like "academic freedom." When left unexamined as a "preconstructed object" (Bourdieu and Wacquant 1992) it might degenerate into a reflex, "an orthodoxy, a right, correct, dominant vision" (Bourdieu, Wacquant, and Farage 1994, 15).

What matters is how autonomy is deployed and there is a danger that it comes to legitimate "academic rule by a managerial executive within the university" (du Toit cited by Southall and Cobbing 2006, 25). University executives are able to manage what autonomy means within a powerful grid of discursive control (Ball 2013) of their making.

Fairclough's body of work around "language as social practice" (Wodak and Fairclough 2009, 7) and shifts in the discourses of higher education (Fairclough 2003, $47-50,64-96,2010)$ offers a powerful lens to understand autonomy and purpose but surprisingly does not feature notions of governmentality. Van Leeuwen's "representation of social action" (van Leeuwen 2008, 23-74) and "the discursive construction of legitimation $(2011,105-123)$ somewhat addresses this gap and shows how various actors are legitimated in governance texts.

The focal point of the paper is a text belonging to the "genre of governance" (Fairclough 2003, 34). Genre is an important concept in CDA theory as it assists us in describing the operationalisation in institutional settings: "genres are important in sustaining the institutional structure of contemporary society as an order of discourse" (Fairclough 2003, 34). The text therefore requires close scrutiny. 


\section{INSTITUTIONAL AUTONOMY AND RELATING TO THE "INTERESTS OF SOCIETY"}

\section{"Regulatory Overkill Threatens Academic Autonomy in South Africa"}

Autonomy is often typified by South African higher education leadership as something that must be aggressively protected from an unnecessarily interfering state (see for example Jansen 2006). In a 2013 article in Business Day, the vice chancellor of UJ, Professor Ihron Rensburg, complains that the Higher Education and Training Laws Amendment Act, puts serious limits on institutional autonomy and freedom and asks if "all of this [regulation] is necessary."

This text (Rensburg 2013), written for a popular audience, by a vice chancellor concerned about the freedom of the post-apartheid university, frames the limits of autonomy squarely in terms of state interference, which is seen as threatening its autonomy:

The act [Higher Education and Training Laws Amendment Act] enhances the powers of the minister to intervene in universities. [He] could appoint assessors and administrators in universities where there was financial and other maladministration, or when a university council requested it. [He is now able] to issue directives to a university council if he believes it has behaved in an unfair or discriminatory manner or against the interests of society. The minister can then appoint an administrator to replace the council should it not comply with such directives. In the case of assessors appointed by the minister, the law previously had not prescribed their powers.

Now the amendments provide copious powers to assessors, transforming their investigations into a formal legal process. The proposed new reporting requirements for universities also enhance the powers of the department by increasing the administrative burden on universities.

Until now universities were, correctly, required to develop a detailed annual report demonstrating that the institution conducts its core business consistent with its vision, mission and strategic plan; how it performs against its key performance targets; its cash flow projections of revenue and expenditure for the following year; and a register of identified and assessed risks and measures to mitigate them.

Now, however, universities are required to prepare a five-year performance plan, and to report to the department twice a year. Specifically, universities must provide an annual report on the previous year by the end of June; a mid-term report by July/August, and an annual update of its performance plan by the end of October.

Is all of this necessary?

Notably, this passage describes what limits autonomy in terms of state interference only rather than in terms of market discipline. It is suggested here that despite its distance from the academy, the state still seeks to maintain a high degree of control over it. Although this view is understandable in a context where state funding of public universities 
has declined, arguably institutional and academic autonomy is as threatened by the vicissitudes of the market as it is by a controlling and abnegating state. This tension is hardly registered in the article beyond a cursory and rather superfluous reference to a "damaging and ideologically driven corporatisation of universities under Margaret Thatcher" (Rensburg 2013).

The refusal to imagine universities as ideological actors in this passage, to enlarge upon their vulnerabilities in relation to various forces in which the market is one, reveals that definitions of autonomy might be partial and falsely disinterested (Bourdieu 1993, 19). Determining what is "necessary" and what is not-necessity being a category that denies autonomy - depends upon defining the purposes of higher education specifically in relation to the "interests of society." But what are these purposes and interests?

"Autonomy" is a slippery term. It can mean the right of the institution to commercialise and privatise its public functions in the face of a shrinking social state, or a greater investment in democratic practice. The elasticity of the concept ostensibly makes it an illusory and "doxic" notion (Bourdieu 2013, 164) —one that conveniently denies the interests at work in universities. It might be used to mask the relationship between the market and the university and its corporatisation.

Rather than being stuck with "autonomy," we might be better served by unpacking critically the rhetorics put forward in asserting the purposes to which public higher education should be put by the higher education system broadly and how universities see their roles (Badat 2009, 4). We might be better served by assuming that discourses of freedom, purpose and autonomy always veil the operations of power within a field of broader social power (Bourdieu 1997, 103).

The article above is clear about who the enemy of autonomy is but unclear as to what the purpose of protecting autonomy might be. Rensburg argues that "the erosion of university autonomy in these new legislative interventions is downright perilous" because "when political leaders are given the power to intervene within autonomous public institutions without any checks or balances" the result is a decline in academic standards. This is shown "north of our borders where universities are simply subject to the dictates of the state" (Rensburg 2013). The question of why the state would intervene in higher education in the first place is not of concern. Ironically, the protection of institutional autonomy from the state can be employed by the state, as Naidoo (2006, 54) argues, to "transfer its powers and responsibilities in the sphere of higher education to the private sector and neo-liberal interests."

No matter how limited, all institutions have purposes and serve particular social interests. In the present context limitations multiply because universities are accountable to various "stakeholders": the state, their "clients," fee-paying customers, shareholders, donors, civil society, government and industry as universities contribute to social mobility (Jansen cited by Herman 2016; Habib and Bawa 2016). They must be publicly accountable. But what does this mean when they have become intensely vulnerable and fragile in capitalist societies, exposed to competition on the knowledge and education market? The decline of state funding (HESA 2008, 17-8) and the inadequacy of state loan 
programmes such as the National Student Financial Aid Scheme, or NSFAS (DoHET $2013,21)$ mean an integral reliance on private student fees, third-stream commercial income generation and donations.

Public universities go out of their way to promote the relevance of their courses to the private sector and job seekers and to show the usefulness of their research to private donors, sometimes at the expense of disciplinary concerns (Mamdani 2007, 42-87), to brand themselves as attractive destinations. However, as they are subsidised, funded and in some senses owned and controlled by the state, public corporatised universities (even if they are corporatised) are not only vulnerable in relation to the market, but are beholden to the government even if control over them has been minimised. Public universities are overseen by the Office of the Minister of Higher Education, must comply in terms of the Higher Education Act (1997), and are quality controlled and regulated by the Council of Higher Education (CHE) and other structures such as professional bodies.

Power is devolved to university level by the state in terms of governance. As is the case at UJ (DHET 2012, 5-7), councils are responsible for appointments, setting fees, admission criteria, offerings, qualification mixes, developing budgets, implementing strategic plans and so on without too much interference or direction from the state. This is mediated by professional, academic and disciplinary demands - embodied in the Senate - for integrity and validity. The tensions inherent in this complicated scenario creates a crisis that becomes visible in a climate of student protest.

In the context of FeesMustFall the question of who the corporatised public university is "accountable" to becomes pressing. Who does the university serve when disciplined by the global market? How are universities to demonstrate their responsibilities operating in contexts of severe underemployment, unemployment, inequality and poverty?

\section{THE UNIVERSITY OF JOHANNESBURG'S GLOBAL EXCELLENCE AND STATURE STRATEGY}

The report discussed above (Bentley, Habib, and Morrow 2006) proposes the "relating" of stakeholders as defining the social purpose of the autonomous, corporatised public university. This view is largely operationalised in the UJ document "Strategic Plan 2025: Tracking Progress towards Achieving Global Excellence and Stature" (hereafter referred to as GES). This is an interesting text because it emphatically evokes marginality"high unemployment, poverty and inequality"-in constructing the autonomy of the University of Johannesburg, but, as I will show in my analysis, fails to materialise a solution.

UJ is an institution that is markedly corporatised and neo-liberal. ${ }^{1}$ The way it speaks about itself and to itself is saturated with promotional language that "re-semanticises" academic life (Holborow 2012). UJ positions itself as a young and ambitious university

1 For a detailed characterisation of the neo-liberal university see Marginson 2013 and Olssen and Peters 2005. 
"anchored in Africa" as well as a newcomer to the global scene of higher education (UJ n.d. "Vision, Mission"). From the popular university "of choice"- the second "coolest brand" amongst the youth (UJ 2014, 2) —UJ presently positions itself in terms of "global excellence and stature" and recently in terms of the "Art of Accomplishment" (SAStudy. co.za n.d.). The idea that the university has of itself as a knowledge actor is futureoriented and competitive (Barnett 2011, 33-44). Internal competitiveness, efficient performance and reputation is of overriding importance (UJ 2014, 32). Corporate social responsibility (UJ n.d. "This Missing Middle") frames its approach to social justice issues including its response to the student protests of 2015.

A powerful hierarchical (UJ n.d. "Executive Leadership Group") managerial and executive culture exists at UJ, one that imposes prescribed standards, accountability and measurement regimes upon the academic community and academic work. Excellence is measured quantitatively, through a disciplining, compulsory and at times punitive performance management system that prioritises output generation against specified targets defined in the GES documentation. R\&D commercialisation efforts, technology transfer, flagship initiatives, patent generation(UJ 2009) and the securing of external sources of funding are crucial to the institution (UJ 2014, 5, 14).

At UJ, the "executive leadership group" (ELG) comprising the vice chancellor, deputy vice chancellors in consultation with executive deans formulate key institutional macro goals and objectives for the university. In 2014 the 46 page document, "Strategic Plan 2025: Tracking Progress towards Achieving Global Excellence and Stature" (UJ 2014) was written and released seemingly as a response to the university being placed in the top four per cent on the Quacquarelli Symonds (QS) World University Rankings league tables (QS 2017). The document, given its strategic importance, requires strong legitimation. The one-page foreword written by the council chairperson and equivalent introduction by the vice chancellor serves this purpose and validates the six key objectives that are subsequently unpacked into a detailed implementation plan.

The objectives are the raison d'être of the document and are presented as states to be achieved by the institution as a whole by 2025 (UJ 2014, 5-6), for example "Excellence in Teaching and Learning," and "National and Global Reputation Management." The GES document is written with a clear governmental purpose in mind: to set out prescribed metrics that will direct institutional change, regulate academic behaviour (Morrissey 2013, 806) and increase managerial control.

The foreword and introduction frame the six strategic objectives in terms of "moral" and "instrumental rationalisations" (van Leeuwen 2008, 113) -rationalisations that perhaps fetishise notions of performance and excellence at the expense of addressing social justice challenges facing South Africa, even if at first glance one might think the opposite is true.

In the opening paragraph (UJ 2014, 1), the council chairperson presents an appeal which suggests a moral support for the strategy as a whole. He acknowledges the epochal issues or socio-economic problems faced by public higher education in contemporary South Africa: 
These are challenging times for higher education in our country, as we continue to experience high unemployment, poverty and inequality in the wider society of which we are a part. These issues put pressure on our higher education system, to serve as the cornerstone of all efforts to radically transform our society, and provide a mechanism that will enable the country to meet these challenges. For the University of Johannesburg (UJ), this calls for radical changes and new ways to improve our teaching and learning, to enhance our research footprint and to ensure that the institution becomes more efficient and effective.

Here, the imaginary reader is "activated" through a shared experience of the "challenging times." This challenge is characterised by "high unemployment, poverty and inequality." What Rose and Miller (2008) might refer to as governmental "problematisation" is here created through an evocation of deficit- "un-employment," "in-equality"- and extremity- "high" unemployment. The aggregated triad of "issues" that makes up the challenging times suggests a potential for this state of affairs to be overcome through purposive social action.

Once the paragraph is grasped in its entirety the reader sees that various "nominalised actors" (Machin and Mayr 2012, 137-38) are portrayed within the narrative of "challenging times." The reader is not sure what specific human agency stands behind them. These actors are presented by the chairperson as 1) the problematisation itselfthe challenges of "high unemployment, poverty and inequality," 2) ("we")-higher education, 3) the "wider society," and 4) "the country."

The problematisation is represented as existing "in" the wider society of which "we"-public higher education-are "a part." Following this logic, it is difficult to locate where the problematisation lies. In public higher education or outside of it? It is not imagined as produced by the system or by society. Evidently, these are challenging times for higher education. Does the fact that public higher education is not "a part" of society but rather an aspect of society that "experiences" its problems absolve the academy from addressing these problems?

The author draws the reader into what seems an all-encompassing "we" where "our" membership in his narrative is assumed by him as given but is undefined. Does the reader of this text include all of us who participate in the project of public higher education or, since it is written as a strategic document, does it refer exclusively to the UJ academic community?

The reader might expect that the chairperson would, given the nature of these "challenging times" and the fact that they are "experienced" by all of us as members, exhort solidarity and action, at least for those the text seems to be addressingacademics, those with potential to create social change. The extensive use of personal and possessive pronouns would be consistent with such an approach. Terms such as "we," "our," the attributive clause "of which we are a part," and the image of the "cornerstone," certainly in a South African context, evoke moral-nationalistic categories such as rainbow nationalism, reconciliation, nation-building, unity, moral regeneration and social cohesion, perhaps positioning readers as "active," educated and responsible citizens in a liberal democracy. However, as is indicated by the personal possessive 
pronoun "our" and the use of "the" rather than "our" wider society, the document expresses ambivalence about where the boundary between higher education and society lies. The vagueness around attribution may suggest that public higher education is not responsible for solving "high unemployment, poverty and inequality."

The ambiguity around assigning responsibility is strongly registered in the superfluity of the adjectival phrase "of which we are a part." Why does the author feel the need to say what may be taken as obvious and given: that public higher education is "part" of the wider society? Surely society is an all-inclusive term? Following this, academics might assume that theirs is a community that is a world apart, distinguished and distinct from society, "autonomous" as it were.

How agency is represented in the chairperson's statement speaks largely to the way in which moral legitimacy and responsible action is understood in terms of the mediating "mechanisms" of governmentality rather than in subject-object relations of narrative representation. The "we" of higher education mediates but does not originate action. The social actors are not represented in a conventional grammatical relation of agency or direct action nor organically, for example, in the stakeholder solidarity of sharing an interest in having social ills addressed.

Action in this passage is represented in non-human terms, with each actor being a mediating element in a causal chain that only leads, as in the case of the previous example, to a state of static relationality. The social actors, "the country," "the wider society" and "higher education," do not consciously work in concert to eliminate "high unemployment, poverty and inequality," but are placed in mechanical and impersonal relation to one another (van Leeuwen 2008, 46). The problems of "high unemployment, poverty and inequality" are transubstantiated into "issues," coldly abstracted and distanced from the actors that could address them. These "issues" put "pressure" on public higher education to serve as the cornerstone of all efforts to radically transform our society, and provide "mechanisms" to achieve the goal of facilitating yet another agent, "the country" to meet these issues. The final responsibility, it seems, is deferred and finally loaded onto the signifier "the country" for resolution.

The "we" of the academic community is cast as a vehicle through which others (the country, "all efforts") realise an ill-defined transformation. It "serves" in an instrumental sense (it does not act on, there is no object or goal to its action) - which entails providing "a mechanism" that does not solve the challenges directly, but in turn "enables" yet another agent, "the country" to "meet" these challenges. The verb "meet," as was the case with "relate" in the 2006 report by Bentley, Habib, and Morrow, discussed earlier, suggests an immaterial, behavioural form of transivity where agency is suspended (van Leeuwen 2008, 66-7).

As it is represented in this text, the university understands itself as a corporate actor that in Bentley Habib, and Morrow's (2006) terms must simply "relate" to the broader society. It is perhaps evacuated of moral agency and ethically incapacitated, serving only to "be" excellent. To refer to Readings $(1996,5)$ it might be asserted that, for the chairperson, the "University no longer participates in the historical project for 
humanity" particularly in its "critical and social" aspects and is thus free from such constraints.

Although the theme of moral responsibility is strongly evoked by the communal and organic metaphors nested in the first sentence of the document, in the second sentence this is nullified with the evocation of eventualisation suggested by images of components, forces, pressures, apparatus, systems. "Challenging times" refers to the interplay of impersonal and inevitable epochal forces (of which unemployment, poverty and inequality are a part) in which public higher education is unfortunately caught up.

The image of the cornerstone stands out here as signalling, in the mind of the author, his essential confusion about how the challenges of "high unemployment, poverty and inequality" are to be addressed as actions. The author could perhaps have used a better architectural metaphor - the keystone - as it is one which actively forms the nexus of pressure exerted by the other components of a building, one that becomes the distributional centre of diverging forces in a building (it is simultaneously the actor and the goal of action). The cornerstone (as opposed to the keystone that actually does useful work) is purely ornamental, decorative, non-functional and passive. It only appears to have an effect, meaning that its inclusion in the overall statement is to make a symbolic, legitimating point.

Public higher education, and by implication the academic community at UJ, is contradictorily objectified in this text, metaphorically as a "cornerstone." It possesses no purposeful and intentional capacity. It can "be" or "serve." The theme of moral deferral implied by the many purpose conjunctions in this statement is clear. The use of a convoluted series of mediating and qualifying grammatical devices "as," "of which," "these," "to" (repeated), "that" confirms this. The vocabularies of forces and mechanisms of deferred action capture the author's imagination.

\section{THE DENIAL OF THE SOCIAL-DESPITE THESE MANY CHALLENGES}

What is most notable about the foreword is the disavowal that takes place in the paragraph below. Because the first paragraph sets out the problem the reader expects the second to solve it. The link between the problem and the solution turns on the word "despite" (UJ 2014, 1; added emphasis) that reinforces the theme of moral deferral implied in my discussion above:

It is pleasing to note, however, that despite these many challenges, the university continued with its excellent performance, and surpassed all its key strategic targets for the last couple of years. These achievements ensured that UJ forged an identity unique among local and international universities, as a well-performing institution. As we continue in our quest to take UJ to greater heights, and boldly enter the international higher education space, we intend to attract and retain illustrious international academic staff, and high performing international students. However, we also realised that these ambitions required a moment to pause and reflect on the appropriateness of our vision and strategic focus, if we are to ensure that UJ remains competitive and attractive as a global institution of learning. 
"Despite" forms the main link or tie between the problematisation of public higher education set out by the chairperson and the achievements of UJ. An agential link could have been easily provided to justify UJ's achievements in social justice terms:

because of UJ's commitment to eradicating high unemployment, poverty and inequality it has put in place programmes that ...

... if we put in place ... the problems of high unemployment, poverty and inequality will be solved ...

... as a result of our experience in dealing with problems of high unemployment, poverty and inequality UJ has ...

Although it would be very easy for the chairperson to legitimate the GES in the terms I have shown above (see van Leeuwen 2008, 110-21), the following approach is preferred:

It is pleasing to note, however, that despite these many challenges, the university continued with its excellent performance, and surpassed all its key strategic targets for the last couple of years.

The word "despite" represents a critical point in the text signalling a major disavowal.

Instead of engaging directly with his own problematisation, "despite" and "however" signal a fundamental indifference toward the country's problems of "high unemployment, poverty and inequality." Although public higher education must provide the "mechanism" to enable the country to "meet" these challenges that "cal[1] for radical changes" and "new ways" to address the problematisation, we are left with no idea as to what this mechanism could be. The refusal to describe the mechanism in precise terms (new models of democracy, inclusive growth, sustainability, redress and restorative justice, progressive income or wealth tax, solidarity economies and so on) and the disavowal of "high unemployment, poverty and inequality" imply that finding solutions are irrelevant to the purpose of UJ. These socio-economic problems are perhaps best be left to "the country" and the "wider society" to solve. Ultimately, these "challenges" distract from what the university essentially is and must continue to be-a well-performing, "effective and efficient" functioning institution. The fact that the socio-economic "challenges" have not affected its smooth functioning is in fact held up here as a badge of distinction.

These "challenges" are not only irrelevant to the work of the academic community but are perceived as obstacles to UJ remaining an efficient and high performing machine. The problems are to be overcome. What is of overriding concern, and this is the rhetorical goal of the statement, is to convince academics that the performance of the university must be measured in the market terms of global recognition and competitiveness and managed so that the problems of high unemployment, poverty and inequality do not interfere with what is a "pleasing" arrangement.

It is imperative that the UJ academic community remains focused on what lies ahead, "surpassing" "its key strategic targets." No link is provided at all as to how these targets might address or are related to the problematisation set out in the first paragraph. 
In this way we might assume that the problems of unemployment, poverty, inequality as they are related to performance, are simply a marketing strategy to demonstrate the excellence of the institution, perhaps indicative of the colonisation of discourse by promotional culture.

\section{ENVISIONING EXCELLENCE AND THE HUMANISATION OF PERFORMANCE}

One might ask why the problematisation is offered in the first place - is it presented as an empty signifier, serving to legitimise UJ's corporate social responsibility programmes? If so social justice issues become a caricatural backdrop to performance.

The foreword sets/reflects the tone for/of the strategic document as a whole. The notion of performance remains defined in terms of tangible outcomes related to global competitiveness and entirely disconnected from the local social issues highlighted above. The fact that the university is performing optimally and aims to perform excellently in the future as "a competitive and attractive," "global institution of learning" is portrayed as highly desirable in and of itself. This requires no warrant. The reader is asked to blindly accept that excellent institutional performance is indicated not in terms of purpose - social use - but in commercial terms through the accumulation of human capital: "attracting and retaining illustrious international academic staff" as well as "high performing international students." In what may be considered a neo-liberal imaginary, "students and academics are governed as sites of human capital" (Heaney 2015, 1) and the institution itself as a responsibilised subject of neo-liberal governmentality, the academic community as an entrepreneurial discourse community (Tikly 2003, 164).

Why devote such attention to what are on face-value somewhat innocuous-looking passages? It is worth noting that the GES objectives and the rationalisations that frame them do not exist as symbolic statements but are systematically unpacked into directives, policies, contracts at every level at the University of Johannesburg and thus there is a strong chance that these are embodied and actualised at the level of practice (which is the subject of another paper). The disavowals at work are extrapolated into strategic objectives, are cascaded into KPIs (Key Performance Indicators) and KPAs (Key Performance Areas) which are linked to numerically defined output targets for existing programmes against which institutional performance is "tracked."

Not surprisingly, the vice chancellor's vision statement for the university (UJ 2014), following the chairperson's statement, continues to disavow and deny the social:

Shifting our identity and brand from new, young and innovative to a university of global excellence and stature is the future we desire for UJ. This new thinking, necessitated the review of the 2020 Strategic Plan, and the development of the 2025 Strategic Plan, anchored in the single strategic goal "Global Excellence and Stature" (GES). The new 2025 strategic plan places a lot of emphasis on "excellence" which is also a recurring theme throughout the six strategic objectives as outlined below. Over the years, UJ has focused on building a reputation 
of accessible excellence, and established itself as an institution of global excellence and world class stature.

The university is here reduced to describable outputs that meet global competitiveness criteria. The challenges of "high unemployment, poverty and inequality" are set aside. Performance is fetishised and humanised (UJ 2014):

All these awards and accolades, and our overall past performance, makes UJ a prominent academic institution in the local and international academic systems, and our willingness to submit credentials for international evaluation is a demonstration of courage, commitment and confidence in our staff and student community at large.

Accomplishment is constructed as the human purpose of the university. Human qualities of courage, commitment and confidence are not attributed to the solving of marginality, unemployment, inequality and poverty per se but are linked to market performance on an international stage, measured by positioning by global university rankings agencies. That, rather than a capacity to engage meaningfully with society, signifies greatness. The humanity of the institution is personified and the desires of its academic discourse community is reflected by "our" willingness and desire to be coldly measured by impersonal global market discipline.

Operationally, its ability to perform efficiently and excellently becomes an overriding concern. Legitimacy is constructed through "instrumental rationalisation" where "purpose is constructed in the action" (van Leeuwen 2008, 114). "Means orientation" is stressed over goal orientation. Notably, in the objectives statements' moral evaluation (the objectives are not referred to in the opening statements), theoretic rationalisation is absent and legitimisation is achieved through means alone. The emphasis on means suggests the overvaluation of technocratic governmentality, resonating with the impersonal mechanisms of the market.

In the absence of positing a convincing relationship between institutional excellence, performance and the socio-economic problematisation the reader must imagine a mythical "mechanism" that will enable "the country" to meet its social justice challenges. This mechanism itself is not provided anywhere in the GES document. Is it the "market mechanism" promoted by Bentley, Habib, and Morrow (2006)? Why is this mechanism favoured when there are many other potential "mechanisms"-political, social, technical, administrative - and modalities available to realise a more just and humane society?

In the absence of being ideologically explicit about such a mechanism, academics, as the main readership of such texts, might themselves not consider social justice to be all that important to the university and fall back upon specious notions of autonomy. As a result of the mystifications, deferrals and disavowals, the academic reader is asked to accept on good faith what might be construed as a neo-liberal, globalist premise: that economic growth, unfettered capitalist development, aggressive commodification, combined with the natural, hidden and beneficent forces of the market will automatically and naturally realise a just public higher education system. 


\section{CONCLUSION}

The texts reveal the extent to which the discourses of neo-liberalism have been adopted and naturalised at the level of governance and strategy in public universities in South Africa. In this paper, I specifically examined how autonomy is leveraged in neo-liberal discourses and governance texts to legitimise the purpose of the corporatised university. Here there is tendency to deny the social and as a result these texts might fail to convince the academic community that the corporatised university is able to deal adequately with problems that are invoked in the name of social justice such as marginalisation, unemployment, poverty and inequality. Social ills are backgrounded and employed as legitimation devices by which the corporatised university celebrates its autonomy in the terms of academic capitalism: global competitiveness, excellence and performance.

\section{REFERENCES}

Baatjes, I. 2005. "Neo-Liberal Fatalism and the Corporatisation of Higher Education in South Africa: Education as Market Fantasy or Education as a Public Good?" Quarterly Review of Education and Training in South Africa 12 (1): 25-33.

Baatjes, I., C. A. Spreen, and S. Vally. 2012. "The Broken Promises of Neo-Liberal Restructuring of South African Higher Education." In Universities and the Public Sphere: Knowledge Creation and State Building in the Era of Globalisation, edited by B. Pusser, K. Kempner, S. Marginson and I. Ordorika, 139-158. London: Routledge.

Badat, S. 2009. "The Role of Higher Education in Society: Valuing Higher Education." Paper presented at the HER-SA Academy, University of Cape Town Graduate School of Business. Accessed July 12, 2016. https://www.ru.ac.za/vicechancellor/speechespresentations/name_58754_en.html

Barnett, R. 2011. Being a University. London: Routledge.

Ball, S. J. 2012a. Global Education Inc.: New Policy Networks and the Neo-Liberal Imaginary. London: Routledge.

Ball, S. J. 2012b. "Performativity, Commodification and Commitment: An I-Spy Guide to the Neo-Liberal University." British Journal of Educational Studies 60 (1): 17-28.

https://doi.org/10.1080/00071005.2011.650940

Ball, S. J. 2013. Foucault, Power and Education. London: Routledge.

Ball, S. J. 2015. "Subjectivity as a Site of Struggle: Refusing Neo-Liberalism?" British Journal of Sociology, 1-18. https://doi.org/10.1080/01425692.2015.1044072

Bentley, K., A. Habib, and S. Morrow. 2006. Academic Freedom, Institutional Autonomy and the Corporatised University in Contemporary South Africa. Pretoria: The Council on Higher Education. 
Bertelsen, E. 1998. “The Real Transformation: The Marketisation of Higher Education.” Social Dynamics 24 (2): 130-58. https://doi.org/10.1080/02533959808458655

Bourdieu, P. 1991. “The Peculiar History of Scientific Reason.” Sociological Forum 6 (1): 3-26. https:// doi.org/10.1007/BF01112725

Bourdieu, P. 1993. The Field of Cultural Production. Cambridge: Polity Press.

Bourdieu, P., 1997. Pascalian Meditations. Cambridge: Polity Press.

Bourdieu, P. 2005. Language and Symbolic Power. Malden: Polity Press.

Bourdieu, P. 2013. Outline of a Theory of Practice. Cambridge: Cambridge University Press.

Bourdieu, P., L. J. D. Wacquant, and S. Farage. 1994. "Rethinking the State: Genesis and Structure of the Bureaucratic Field.” Sociological Theory 12 (1): 1-18. https://doi.org/10.2307/202032

Bourdieu, P., and L. J. D. Wacquant. 1992. An Invitation to Reflexive Sociology. Chicago: University of Chicago Press.

Chetty, N., and C. Merrett. 2014. The Struggle for the Soul of a South African University: The University of Kwazulu-Natal, Academic Freedom, Corporatisation and Transformation. Pietermaritzburg: Selfpublished.

Cooper, D. 2015. 'Social Justice and South African University Student Enrolment Data by 'Race', 19982012: From 'Skewed Revolution' to 'Stalled Revolution."' Higher Education Quarterly 69 (3): 237-62. https://doi.org/10.1111/hequ.12074

DHET (Department of Higher Education and Training). 2012. "Amendments to the Institutional Statute of the University of Johannesburg." Higher Education Act, 1997 (Act No. 101 Of 1997). Accessed November 16, 2017. http://www.gov.za/sites/www.gov.za/files/34954_gon44.pdf

DHET (Department of Higher Education and Training). 2013. Report of the Ministerial Committee for the Review of the Funding of Universities. Pretoria: Department of Higher Education and Training. Accessed November 16, 2017. http://www.dhet.gov.za/Financial\%20and\%20Physical\%20Planning/ Report\%20of\%20the\%20Ministerial\%20Committee \%20for\%20the\%20Review\%20of\%20the\%20 Funding $\% 20 \mathrm{of} \% 20$ Universities.pdf

Du Gay, P. 2006. “Organising Identity: Making Up People at Work.” In Production of Culture/Cultures of Production, edited by P. du Gay, 286-340. London: Sage.

du Toit, A. 2000. "From Autonomy to Accountability: Academic Freedom under Threat in South Africa?" Social Dynamics 26 (1): 76-133. https://doi.org/10.1080/02533950008458687

du Toit, A. 2007. Autonomy as a Social Compact. Pretoria: Council on Higher Education. Accessed November 16, 2017. http://www.che.ac.za/sites/default/files/publications/Autonomy_du_Toit_ Feb2007.pdf

Fairclough, N. 2003. Analysing Discourse: Textual Analysis for Social Research. London: Routledge.

Fairclough, N. 2008. Language and Globalisation. London: Routledge. 
Habib, A. 2009. "Managing Higher Education Institutions in Contemporary South Africa: Advancing Progressive Agendas in a Neo-Liberal and Technicist World." Paper presented at First thoughts at the Higher Education Roundtable, Rhodes University, Grahamstown, October 27-29.

Habib, A. 2013. "Reflections of a University Bureaucrat Interested in Advancing a Progressive Social Agenda." In The Aims of Higher Education, Kagisano 9, by the Council on Higher Education, 63-75. Pretoria: Council on Higher Education.

Habib, A., and A. Bawa. 2016. "Survival of Universities Requires Realism on Fees." Sunday Times, July 17. Accessed November 16, 2017. https://www.timeslive.co.za/sunday-times/opinion-and-analysis/201607-17-survival-of-universities-requires-realism-on-fees/

Heaney, C. 2015. "What Is the University Today?” Journal for Critical Education Policy Studies 13 (2): 287-314.

Herman, P. 2016. “Another 0\% Fee Increase Will Destroy SA Universities - Jansen.” News 24, August 26. Accessed November 14, 2017. www.news24.com/SouthAfrica/another-0-fee-increase-will-destroysa-universities-jansen-20160825

HESA (Higher Education South Africa). 2008. Tuition Fees. Higher Education Institutions in South Africa. Pretoria: HESA Task Team. Accessed November 15, 2017. http://www.justice.gov.za/ commissions/FeesHET/docs/2008-HESA-Report-TuitionFeesInSA.pdf

Holborow, M. 2012. "Neo-Liberal Keywords and the Contradictions of an Ideology." In Neo-Liberalism and Applied Linguistics, edited by D. Block., J. Gray and M. Holborow, 33-55. London: Routledge.

Jansen, J. D. 2006. “Accounting for Autonomy.” In Asinamali: University Struggles in Post-Apartheid South Africa, edited by R. Pithouse, 11-23. Asmara: Africa World Press.

Lasslett, K. 2015. "The State at the Heart of Capitalism: Marxist Theory and Foucault's Lectures on Governmentality." Critical Sociology 41 (5): 641-58. https://doi.org/10.1177/0896920513518948

Lemke, T. 2002. "Foucault, Governmentality, and Critique." Rethinking Marxism: A Journal of Economics, Culture and Society 14 (3): 49-64. https://doi.org/10.1080/089356902101242288

Machin, D., and A. Mayr. 2012. How to Do Critical Discourse Analysis. New Delhi: Sage.

Mamdani, M. 2007. Scholars in the Marketplace: The Dilemmas of Neo-Liberal Reform at Makerere University 1989-2005. Cape Town: HSRC Press.

Marginson, S. 2013. "The Impossibility of Capitalist Markets in Higher Education.” Journal of Education Policy 28 (3): 353-70. https://doi.org/10.1080/02680939.2012.747109

Morrissey, J. 2013. "Governing the Academic Subject: Foucault, Governmentality and the Performing University." Oxford Review of Education 39 (6): 797-810.

https://doi.org/10.1080/03054985.2013.860891

Naidoo, P. 2006. "'Constituting the Class': Neo-Liberalism and the Student Movement in South Africa." In Asinamali: University Struggles in Post-Apartheid South Africa, edited by R. Pithouse, 51-69. Asmara: Africa World Press. 
Nash, A., 2006. "Restructuring South African Universities." In Asinamali: University Struggles in PostApartheid South Africa, edited by R. Pithouse, 1-11. Asmara: Africa World Press.

Ntshoe, I. M. 2004. "Higher Education and Training Policy and Practice in South Africa: Impacts of Global Privatisation, Quasi-Marketisation and New Managerialism." International Journal of Educational Development 24 (2): 137-54. https://doi.org/10.1016/j.ijedudev.2003.10.006

Olssen, M., and M. A. Peters. 2005. "Neo-Liberalism, Higher Education and the Knowledge Economy: From Free Market to Knowledge Capitalism.” Journal of Education Policy 20 (3): 313-45. https://doi.org/10.1080/02680930500108718

Pendlebury, J., and L. van der Walt. 2006. "Neo-Liberalism, Bureaucracy and Resistance at Wits University." In Asinamali: University Struggles in Post-Apartheid South Africa, edited by R. Pithouse, 79-92. Asmara: Africa World Press.

Peters, M. D. 2009. “Neo-Liberal Governmentality: Foucault on the Birth of Bio Politics." In Governmentality Studies in Education, edited by M. D. Peters, A. C. Besley, M. Olssen, S. Maurer and S. Weber, 95-109. Rotterdam: Sense publishers.

QS Top Universities. 2017. “World University Rankings 2018.” Accessed November 15, 2017. http://www.topuniversities.com/qs-world-university-rankings

Readings, B. 1996. The University in Ruins. Cambridge, MA: Harvard University Press.

Republic of South Africa. 1997. Higher Education Act 1997. Government Gazette Vol. 390 No. 18515. Cape Town: Office of the President. Accessed November 15, 2017. http://www.gov.za/sites/www.gov.za/files/a101-97.pdf

Rensburg, I., 2013. "Regulatory Overkill Threatens Academic Autonomy in South Africa." Business Day, January 31. Accessed November 14, 2017. http://www.chet.org.za/news/regulatory-overkillthreatens-academic-autonomy

Rose, N., and P. Miller. 2008. Governing the Present: Administering Economic, Social and Personal Life. Cambridge: Polity Press.

SAStudy.co.za. n.d. "UJ's Art of Accomplishment.” Accessed November 15, 2017. http://sastudy.co.za/article/ujs-art-of-accomplishment/

Slaughter, S. 2014. "Retheorising Academic Capitalism Actors, Mechanisms, Fields, and Networks." In Academic Capitalism in the Age of Globalisation, edited by B. Cantwell and I. Kauppinen, 10-32. Baltimore: Johns Hopkins University Press

Southall, R., and J. Cobbing. 2006. "From Racial Liberalism to Corporate Authoritarianism." In Asinamali: University Struggles in Post-Apartheid South Africa, edited by R. Pithouse, 23-39. Asmara: Africa World Press.

Spreen, C. A., and S. Vally. 2006. "Education Rights, Education Policies and Inequality in South Africa." International Journal of Educational Development 26 (4): 352-62. https://doi.org/10.1016/j.ijedudev.2005.09.004 
Tikly, L. 2003. "Governmentality and the Study of Education Policy in South Africa." Education Policy 18 (2): 161-74. https://doi.org/10.1080/0268093022000043074

UJ (The University of Johannesburg). 2009. "Policy on the Protection, Management and Commercial Exploitation of Intellectual Property."Accessed March 3, 2016.https://www.uj.ac.za/ corporateservices/commercialisation/Documents/INTELLECTUAL\%20PROPERTY.pdf

UJ (The University of Johannesburg). 2014. "Strategic Plan 2025: Tracking Progress towards Achieving Global Excellence and Stature." Accessed August 25, 2016. https://www.uj.ac.za/about/Documents/ Strategic\%20Plan\%202025.pdf.

UJ (The University of Johannesburg). n.d. "Executive Leadership Group.” Accessed November 14, 2017. https://www.uj.ac.za/about/Pages/Leadership-Structure.aspx

UJ (The University of Johannesburg). n.d. "The Missing Middle." Accessed March 2, 2016. https://www.uj.ac.za/corporateservices/give2uj/The\%20Missing\%20Middle/Pages/default.aspx

UJ (The University of Johannesburg). n.d. "Mission, Vision and Values." Accessed March 2, 2016. https://www.uj.ac.za/about/Pages/vision-mission-and-values.aspx

Vally, S. 2007a. "From People's Education to Neo-Liberalism in South Africa." Review of African Political Economy 34 (111): 39-56. https://doi.org/10.1080/03056240701340258

Vally, S. 2007b. "Higher Education in South Africa: Market, Mill or Public Good?" Journal of Higher Education in Africa 5 (1): 17-28.

Van Leeuwen, T. 2008. Discourse and Practice: New Tools for Critical Discourse Analysis. Oxford: Oxford University Press.

Wacquant, L. 2009. Punishing the Poor: The Neo-Liberal Government of Social Insecurity. Durham: Duke University Press. https://doi.org/10.1215/9780822392255

Wodak, R., and M. Meyer. 2009. "Critical Discourse Analysis: History, Agenda, Theory, and Methodology." In Methods for Critical Discourse Analysis, edited by R. Wodak and M. Meyer, 1-33. London: Sage. 